\title{
Sex identification in embryos and adults of Darwin's finches
}

\author{
Mariya P. Dobreva ${ }^{1}{ }^{*}$, Joshua G. Lynton-Jenkins $\oplus^{2 *}$, Jaime A. Chaves ${ }^{3,4}$, \\ Masayoshi Tokita ${ }^{5 \mathrm{aa}}$, Camille Bonneaud $\mathbb{D}^{2}$, Arkhat Abzhanov ${ }^{5 \mathrm{ab}}$
}

1 Department of Life Sciences (Silwood Park), Imperial College London, Ascot, United Kingdom, 2 Centre for Ecology and Conservation, University of Exeter, Penryn, United Kingdom, 3 Department of Biology, San Francisco State University, San Francisco, California, United States of America, 4 Colegio de Ciencias Biológicas y Ambientales, Campus Cumbayá, Universidad San Francisco de Quito, Cumbayá, Quito, Ecuador, 5 Department of Organismic and Evolutionary Biology, Harvard University, Cambridge, Massachusetts, United States of America

a Current address: Department of Biology, Toho University, Funabashi, Chiba, Japan ab Current address: Department of Life Sciences (Silwood Park), Imperial College London, Ascot, United Kingdom

* mimi.pen@gmail.com (MPD); j1462@exeter.ac.uk (JGLJ)

\section{G OPENACCESS}

Citation: Dobreva MP, Lynton-Jenkins JG, Chaves JA, Tokita M, Bonneaud C, Abzhanov A (2021) Sex identification in embryos and adults of Darwin's finches. PLOS ONE 16(3): e0237687. https://doi. org/10.1371/journal.pone.0237687

Editor: Anton Wutz, Eidgenossische Technische Hochschule Zurich, SWITZERLAND

Received: July 29, 2020

Accepted: February 16, 2021

Published: March 5, 2021

Peer Review History: PLOS recognizes the benefits of transparency in the peer review process; therefore, we enable the publication of all of the content of peer review and author responses alongside final, published articles. The editorial history of this article is available here: https://doi.org/10.1371/journal.pone.0237687

Copyright: @ 2021 Dobreva et al. This is an open access article distributed under the terms of the Creative Commons Attribution License, which permits unrestricted use, distribution, and reproduction in any medium, provided the original author and source are credited.

Data Availability Statement: All relevant data are within the paper and its Supporting Information file.

Funding: MPD has received funding from the European Union's Horizon 2020 research and

\section{Abstract}

Darwin's finches are an iconic example of adaptive radiation and evolution under natural selection. Comparative genetic studies using embryos of Darwin's finches have shed light on the possible evolutionary processes underlying the speciation of this clade. Molecular identification of the sex of embryonic samples is important for such studies, where this information often cannot be inferred otherwise. We tested a fast and simple chicken embryo protocol to extract DNA from Darwin's finch embryos. In addition, we applied minor modifications to two of the previously reported PCR primer sets for CHD1, a gene used for sexing adult passerine birds. The sex of all 29 tested embryos of six species of Darwin's finches was determined successfully by PCR, using both primer sets. Next to embryos, hatchlings and fledglings are also impossible to distinguish visually. This extends to juveniles of sexually dimorphic species which are yet to moult in adult-like plumage and beak colouration. Furthermore, four species of Darwin's finches are monomorphic, males and females looking alike. Therefore, sex assessment in the field can be a source of error, especially with respect to juveniles and mature monomorphic birds outside of the mating season. We caught 567 juveniles and adults belonging to six species of Darwin's finches and only $44 \%$ had unambiguous sex-specific morphology. We sexed 363 birds by PCR: individuals sexed based on marginal sex specific morphological traits; and birds which were impossible to classify in the field. PCR revealed that for birds with marginal sex specific traits, sexing in the field produced a $13 \%$ error rate. This demonstrates that PCR based sexing can improve field studies on Darwin's finches, especially when individuals with unclear sex-related morphology are involved. The protocols used here provide an easy and reliable way to sex Darwin's finches throughout ontogeny, from embryos to adults. 
innovation programme under the Marie Sklodowska-Curie grant agreement No 702707. JGLJ was supported by Heredity Fieldwork Grant awarded by The Genetics Society, and by University of Exeter Vice Chancellor's scholarship for post-graduate research. JAC and CB received a field work collaboration grant by the Universidad San Francisco de Quito (Ecuador). MT was supported by Japan Society for the Promotion of Science (JSPS) - Postdoctoral Fellowship for research abroad No 23-771, and The Uehara Memorial Foundation Research Fellowship. The funders had no role in study design, data collection and analysis, decision to publish, or preparation of the manuscript.

Competing interests: The authors have declared that no competing interests exist.

\section{Introduction}

Accurate and rapid sex identification is an important step in many research projects. Distinguishing sex by morphological traits like colouration and ornamentation can be straightforward in mature sexually dimorphic birds. Often however, such traits develop gradually and younger birds of both sexes look alike [1]. This makes visual sexing of nestlings, fledglings and young adults difficult to impossible. In addition, some species of birds only show clear dimorphic traits during the mating season, with males moulting into a less exaggerated plumage when not breeding [2]. Avian embryos cannot be sexed based on external observation only. Dissections for sexing based on embryonic gonadal morphology is time-consuming and might not be possible in all species, and is impossible in earlier developmental stages [3]. Furthermore, visual sexing can be difficult or impossible in monomorphic species of birds. In these cases, behavioural observations including singing, or morphometric measurements could be used, but these are not always applicable and can be expensive, inaccurate and time-consuming [4]. The presence of a brood patch can be used to recognise the incubating sex, but this is a temporary trait, not all species develop it, and it is not discriminative when both sexes incubate [5]. Cloacal protuberances in males are visible only during breeding and are not always clearly distinguishable [6].

Darwin's finches are endemic to the Galápagos and Cocos islands and represent a classical example of adaptive radiation under natural selection [7]. This unique group of birds has contributed significantly to the study of evolutionary processes. There is a constantly growing body of literature on their morphology, population genetics, genomics, behaviour, physiology, development, ecology, biomechanics, conservation, etc. [7-10]. Comparing the unfolding of genetic programs during development among different species of Darwin's finches has provided insight into the possible evolutionary mechanisms behind the extraordinary radiation of this group of birds [11-15]. Sexing embryos of Darwin's finches is important for further research, for instance when evaluating possible sex bias in comparative gene expression analyses.

Molecular sexing of post-embryonic Darwin's finches can be useful as well. It is especially relevant for birds in their first months of life, when both sexes look alike in all species [16]. In sexually dimorphic species, males develop their mature plumage colouration gradually over time-a process that usually starts around the end of their first year and takes several years [16-18]. In ground, cactus and sharp-beaked finches (genus Geospiza, 6 species), males develop their adult black plumage and beak colour over 4-6 years, with young males resembling the brown, streaked and pale-beaked females $[8,17]$. Similarly, in tree finches (genus Camarhynchus, 3 species) it takes a year for the males to start developing the black colour of their heads, which is fully attained in 5 years, while females remain brown and streaked [18]. Other dimorphic species are the vegetarian finch Platyspiza crassirostris and the Cocos' island finch Pinaroloxias inornata [16]. There are four monomorphic species of Darwin's finches: the woodpecker and mangrove finches Camarhynchus pallidus and C. heliobates, and the warbler finches Certhidea olivacea and C. fusca [16]. Mature birds can be sexed by behavioural observations-especially singing_as only male Darwin's finches sing $[16,17,19,20]$. However, males typically sing only during the mating season, and this approach is not applicable for mist-net captured birds. Only female Darwin's finches incubate the eggs, and the brood patch is a definitive female trait [16]. But brood patches and cloacal protuberances are temporary traits as well. Thus, molecular sexing is important for both juvenile Darwin's finches of all species and mature monomorphic individuals.

The heterogametic sex in birds is female with $\mathrm{Z}$ and $\mathrm{W}$ sex chromosomes, while males have two $\mathrm{Z}$ chromosomes [21]. Currently, the most widely used methodology for molecular sexing 
in birds is polymerase chain reaction (PCR) to amplify sex chromosome-specific fragments, followed by electrophoretic analysis [4]. Earlier attempts at avian sexing involved amplification of a $\mathrm{W}$-specific repetitive sequence $[3,22,23]$ to allow detection of the female sex only. Later, the chromodomain helicase DNA binding 1 (CHD1) became the most widely used gene for non-ratite avian sex identification [4]. The $\mathrm{Z}$ and $\mathrm{W}$ chromosomes carry very closely related, but not identical copies of the CHD1 gene [24, 25]. CHD1Z and CHD1W differ slightly in the size and sequence of some intronic regions allowing the detection of two versions of the gene in the heterogametic females and one in the homogametic males. CHD1 is a highly conserved gene, which makes it a candidate for universal non-ratite avian sex identification. A number of studies have reported specific PCR primers to screen the intron variants of the $\mathrm{Z}$ and $\mathrm{W}$ alleles and have successfully applied these to many avian species [26-30]. The difference between the size of the male and female fragments varies between species and primer pairs. We chose two CHD1 primer pairs reported previously: CHD1F/CHD1R [28] and P2/P8 [26]. Within passerines, the documented difference between the male and female fragments is 193-202 bp for CHD1F/CHD1R and 10-64 bp for P2/P8 [27].

PCR sexing of avian embryos was first established in chicken (Gallus g. domesticus) - a widely used model species in developmental biology [23]. Chicken embryos are sexed through amplification of a $\mathrm{W}$-specific repetitive sequence and an 18-S ribosomal gene sequence as a PCR control, thus detecting only the female sex [3, 23, 31, 32], or via CHD1-specific primers [33]. Embryos of zebra finch (Taeniopygia guttata) - a model passerine bird species-have been sexed with CHD1 primer pairs described by Griffiths [26], or modifications of these [34, 35]. Sexing of embryos of Darwin's finches has not been previously reported. In juveniles and adults, attempts to sex the monomorphic woodpecker finch using DNA from blood samples were unsuccessful-results from sexing based on singing did not match the results from molecular testing $[19,20]$. The lack of clear sexing has led to complications of the captivity breeding plans for the endangered mangrove finch [20]. Further sexing using data from Zlinked microsatellites was used only on 10 woodpecker finches and was inconclusive for one bird (10\% failure rate) [36].

Here, we isolated DNA from embryonic tissues and adult wing vein blood and modified two CHD1 primer pairs: CHD1F/CHD1R [28], and P2/P8 [26]. We tested modified (m)P2/P8 on embryonic DNA and mCHD1F/mCHD1R on both adult and embryonic DNA of Darwin's finches. We successfully identified the sex of all tested individuals and found that sexing based on morphological characteristics can be a source of error.

\section{Materials and methods}

\section{Sampling and sexing in the field}

Embryos and fledged birds from natural populations were sampled under permits issued by Ministerio del Ambiente del Ecuador (Ecuadorian Ministry of the Environment, Acceso al Recurso Genético MAE-DNB-CM-2016-0041) and by Galápagos National Park (PC-08-13; PC-34-14; PC-03-18; PC-28-19). Sampling of fledged birds was also approved by University of Exeter's Research Ethics Committee (eCORN000054) and conducted according to the Animals (Scientific Procedures) Act 1986. Avian embryos of developmental stages used in this study are not regulated animals in USA and UK. Embryos $(n=29)$ from six species of Darwin's finches were collected on Santa Cruz and Pinta in 2013-2015 (6 Geospiza fuliginosa, 5 G. fortis, 5 G. magnirostris, 7 Camarhynchus psittacula, 1 C. parvulus, and 5 Platyspiza crassirostris) using previously described methods [37]. Only one egg per nest was collected to minimize the impact on populations. Eggs were incubated for 7 days in the field at $38^{\circ} \mathrm{C}$ and $60 \%$ humidity. Embryos were decapitated, immersed in RNAlater (Sigma-Aldrich) and frozen. Fertilized 
zebra finch embryos were obtained from Queen Mary University of London and incubated and stored using the same conditions. Fledged birds $(n=567)$ were caught using mist-nets on San Cristobal and Santa Cruz in 2018 and 2019. We sampled representatives of six species of Darwin's finches (422 Geospiza fuliginosa, 102 G. fortis, 11 G. scandens, 4 Camarhynchus pallidus, 21 C. parvulus, and 7 Certhidea fusca). Blood was collected by brachial venepuncture as described in [38]. After sampling, each bird was given water and immediately released. Where possible, we determined sex based on: plumage colouration, from female-like brown plumage to five categories of black coloration in males towards full adult black plumage [39]; the presence of a brood patch in females; and of a cloacal protuberance in males during breeding.

\section{DNA extraction}

Embryonic DNA was extracted using the alkaline method described in [31], with subtle modifications. Firstly, a small piece of soft tissue $(5-25 \mathrm{mg})$ was dissected from the head or tail regions of mid-incubation embryos preserved in RNAlater (from stages 30-34 [40]). Samples were immersed in $40 \mu \mathrm{l} 0.2 \mathrm{~N} \mathrm{NaOH}$, vortexed for 15 seconds and lysed at $80^{\circ} \mathrm{C}$ for 25 minutes. Samples were then placed on ice for $1 \mathrm{~min}$, vortexed for $15 \mathrm{sec}$ and $\mathrm{pH}$-neutralized with $300 \mu \mathrm{l}$ $0.04 \mathrm{M}$ Tris- $\mathrm{HCl}$ (pH 7.75). We used $2 \mu \mathrm{l}$ per $20 \mu \mathrm{l}$ PCR reaction. While most embryonic samples worked using the unpurified DNA as a template, several did not show bands in the following gel analysis. In these cases, we diluted the extracted DNA in water (1:10) and used $4 \mu \mathrm{l}$ for PCR, which resulted in clear bands. Adult DNA was extracted from blood samples using

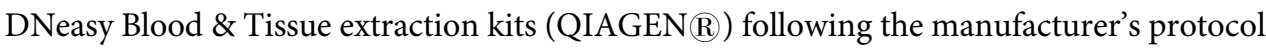
for nucleated blood. Extractions were standardised to a concentration of $25 \mathrm{ng} / \mu \mathrm{l}$.

\section{PCR amplification, sequencing, and gel visualization}

We aligned the sequences (BLASTn) of the CHD1F and CHD1R [28], and P2 and P8 [26] primers to those species of interest with published genomes: zebra finch (T. guttata) and medium ground finch (Geospiza fortis). We chose these primer sets because they have been assessed as most successful across passerine birds (Passeriformes) [27]. Based on the alignment results, we substituted the specified nucleotides so that the primer sequences match more closely the corresponding CHD1 region of T. guttata and G. fortis (Table 1). We did not change the sequence of P8. The PCR reaction mixture contained 2.5 units Taq polymerase and $1 \mathrm{x}$ PCR buffer (D1806, Sigma-Aldrich), $0.25 \mathrm{mM}$ dNTP mix and $0.5 \mu \mathrm{M}$ of each of the primers. For mCHD1F/mCHD1R, amplification conditions were: 4 min at $94^{\circ} \mathrm{C}$ followed by 40 cycles of $94^{\circ} \mathrm{C}$ for $30 \mathrm{sec}, 56^{\circ} \mathrm{C}$ for $30 \mathrm{sec}$ and $72^{\circ} \mathrm{C}$ for 45 , and a final extension for $5 \mathrm{~min}$ at $72^{\circ} \mathrm{C}$. For $\mathrm{mP} 2 / \mathrm{P} 8$, the same conditions applied but the annealing temperature used was $51^{\circ} \mathrm{C}$. $\mathrm{PCR}$

Table 1. Primer sequences.

\begin{tabular}{|c|c|}
\hline Primer name elsewhere & Sequence 5'-3' \\
\hline CHD1F (Lee et al. 2010) & TATCGTCAGTTTCCTTTTCAGGT \\
\hline CHD1R (Lee et al. 2010) & ССTTTTATTGATCCATCAAGCCT \\
\hline P8 (Griffiths et al. 1998) & CTCCCAAGGATGAGRAAYTG \\
\hline P2 (Griffiths et al. 1998) & TCTGCATCGCTAAATCCTTT \\
\hline Primer name in this study & Modified sequence 5'-3' \\
\hline $\mathrm{mCHD} 1 \mathrm{~F}$ & TATCGTCAGTTTCCVITTCAGGT \\
\hline $\mathrm{mCHD} 1 \mathrm{R}$ & CCTTTTATTGATCCATCAAG $\underline{\mathbf{T}} \mathrm{CT}$ \\
\hline $\mathrm{mP} 2$ & TCTGCATCRCTAAATCCTTT \\
\hline
\end{tabular}

Modifications of previously published primers are underlined.

https://doi.org/10.1371/journal.pone.0237687.t001 
products were visualized by electrophoresis on agarose gel containing GelRed (Biotium) and band sizes were evaluated against a $100 \mathrm{bp}$ molecular weight marker (NEB). We analysed $\mathrm{mCHD} 1 \mathrm{~F} / \mathrm{mCHD} 1 \mathrm{R}$ fragments on $2 \%$ gel for $1 \mathrm{~h}, 90 \mathrm{~min}$ and $2 \mathrm{~h}$ at $4 \mathrm{~V} / \mathrm{cm}$. $\mathrm{mP} 2 / \mathrm{P} 8$ products were analysed on $2.5 \%$ or $3 \%$ gel for time points between 2 hours and 3 hours $30 \mathrm{~min}$ at $4-4.5 \mathrm{~V} / \mathrm{cm}$. PCR products were sequenced by Macrogen Europe B.V. and sequences were identified using BLASTn (NCBI).

\section{Results}

We aimed to amplify a section of the CHD1 gene to identify the sex of nine species of Darwin's finches. Using our primer pairs (Table 1), we expected fragment size ranges (based on results from Passeriformes [27]) as follows: for mCHD1F/mCHD1R, 328-345 bp for W and 455-696 bp for Z; for mP2/P8, 339-398 bp for W and 316-371 bp for Z.

First, we analysed the DNA of embryonic samples of six species of Darwin's finches, and of the widely used passerine model species-the zebra finch (T. guttata). We analysed 39 embryonic samples: 10 of zebra finch and 29 embryos of Darwin's finches. DNA was extracted from embryonic tissue using the most rapid published protocol [31] with minimal modifications. All embryonic samples were amplified successfully using both $\mathrm{mCHD} 1 \mathrm{~F} / \mathrm{mCHD} 1 \mathrm{R}$ and $\mathrm{mP} 2 /$ P8 primer pairs (Table 2). Samples with a single band were identified as males, and ones with two bands-as females. Fig 1 shows the electrophoresis results of 4 zebra finch and 17 Darwin's finch embryonic samples. The $\mathrm{mCHD} 1 \mathrm{~F} / \mathrm{mCHD} 1 \mathrm{R}$ PCR products were analysed on $2 \%$ agarose gel at $4 \mathrm{~V} / \mathrm{cm}$ for 90 minutes for optimal band separation (Fig 1A), but shorter running times (e.g., $60 \mathrm{~min}$ ) were also successful. To confirm the PCR results, we sequenced the PCR product of 13 of the samples, as follows: one male and one female per species for T. guttata, G. magnirostris, G. fortis, G. fuliginosa, C. psittacula, and P. crassirostris; and the only individual for C. parvulus (male). Table 2 shows the top BLASTn result for CHD1 or CHD1 homologs for each sequence, along with the E-value and the avian species with highest score. All BLASTn results for male embryos showed similarity with $C H D 1 Z$ and not with $C H D 1 W$. Conversely, all results for female embryos showed similarity to both $C H D 1 Z$ and $C H D 1 W$. We analysed the $\mathrm{mP} 2 / \mathrm{P} 8 \mathrm{PCR}$ products on $3 \%$ gel at $4.25 \mathrm{~V} / \mathrm{cm}$ for 3 hours 30 minutes to achieve a very clear separation of the two bands, expected to have a small fragment size difference based on the data across other Passeriformes species (10-64 bp, [27]) (Fig 1B). Our tests showed that the two bands already separated on $2.5 \%$ gel at $4 \mathrm{~V} / \mathrm{cm}$ for 2 hours and these timesaving conditions can be used instead. Both primer pairs tested on embryonic DNA produced clearly distinguishable bands and the results obtained from the two pairs correlate to each other (Table 2).

In addition, we aimed to sex 567 mist-net captured birds of six species of Darwin's finches through a combination of morphological and genetic sexing approaches. The design of the study did not allow collection of behavioural data. Sex was clearly identified by morphology in 250 birds, based on plumage coloration and/or presence of brood patch or cloacal protuberance. 46 of these were analysed by PCR to validate the approach. All PCR sexing results matched morphological sex assignment. From the remaining 317 birds, 39 did not show any morphological traits that could be used for sexing and were not assigned sex. These included: males that had not started developing adult coloration or were monomorphic; females that were not incubating and had no brood patch; and males not in active breeding without cloacal protuberance. The other 278 birds did not show a clear sex-specific morphological trait but were assigned sex based on a partially clear, marginal trait. These could include males in early stages of development of adult colouration, or females with forming but unclear brood patch. The sex of these individuals was to be confirmed using PCR. Blood samples were amplified successfully using the $\mathrm{mCHD} 1 \mathrm{~F} / \mathrm{mCHD} 1 \mathrm{R}$ primer pair. Fig 2 shows the electrophoretic 
Table 2. List of embryonic samples analysed in Fig 1, and sexing and sequencing results.

\begin{tabular}{|c|c|c|c|c|c|c|c|c|}
\hline \multirow[t]{2}{*}{ Lane in Fig 1} & \multirow[t]{2}{*}{ Sample name } & \multirow[t]{2}{*}{ P8/mP2 } & \multirow[t]{2}{*}{ mCHD1F/mCHD1R } & \multicolumn{3}{|c|}{ BLAST } & \multicolumn{2}{|c|}{$\begin{array}{c}\text { Total per } \\
\text { species }\end{array}$} \\
\hline & & & & CHD1 variant & Species & E-value & $\mathbf{F}$ & M \\
\hline \multirow[t]{2}{*}{1} & \multirow[t]{2}{*}{ Taeniopygia guttata-1 } & \multirow[t]{2}{*}{$\mathrm{F}$} & \multirow[t]{2}{*}{$\mathrm{F}$} & CHD1W & Corvus frugilegus & 6.E-60 & \multirow[t]{5}{*}{5} & \multirow[t]{5}{*}{5} \\
\hline & & & & CHD1Z & Taeniopygia guttata & 1.E-42 & & \\
\hline 2 & Taeniopygia guttata-2 & $\mathrm{F}$ & $\mathrm{F}$ & & & & & \\
\hline 3 & Taeniopygia guttata-3 & M & M & CHD1Z & Taeniopygia guttata & $0 . \mathrm{E}+00$ & & \\
\hline 4 & Taeniopygia guttata-4 & M & M & & & & & \\
\hline \multirow[t]{2}{*}{5} & \multirow[t]{2}{*}{ Geospiza magnirostris-1 } & \multirow[t]{2}{*}{$\mathrm{F}$} & \multirow[t]{2}{*}{$\mathrm{F}$} & $C H D 1 W$ & Cardinalis cardinalis & 1.E-76 & \multirow[t]{4}{*}{4} & \multirow[t]{4}{*}{1} \\
\hline & & & & CHD1Z & Motacilla flava pygmaea & 1.E-52 & & \\
\hline 6 & Geospiza magnirostris-2 & $\mathrm{F}$ & $\mathrm{F}$ & & & & & \\
\hline 7 & Geospiza magnirostris-3 & M & M & CHD1Z & Melanospiza richardsoni & 3.E-148 & & \\
\hline 8 & Geospiza fortis-1 & $\mathrm{F}$ & $\mathrm{F}$ & & & & \multirow[t]{4}{*}{4} & \multirow[t]{4}{*}{1} \\
\hline \multirow[t]{2}{*}{9} & \multirow{2}{*}{ Geospiza fortis-2 } & \multirow[t]{2}{*}{$\mathrm{F}$} & \multirow[t]{2}{*}{$\mathrm{F}$} & CHDIW & Cardinalis cardinalis & 3.E-73 & & \\
\hline & & & & CHD1Z & Pomarea dimidiata & 6.E-50 & & \\
\hline 10 & Geospiza fortis-3 & M & M & CHD1Z & Sporophila caerulescens & 2.E-150 & & \\
\hline 11 & Geospiza fuliginosa-1 & $\mathrm{F}$ & $\mathrm{F}$ & & & & \multirow[t]{4}{*}{5} & \multirow[t]{4}{*}{1} \\
\hline \multirow[t]{2}{*}{12} & \multirow[t]{2}{*}{ Geospiza fuliginosa-2 } & \multirow[t]{2}{*}{$\mathrm{F}$} & \multirow[t]{2}{*}{$\mathrm{F}$} & CHD1W & Emberiza schoeniclus & 1.E-27 & & \\
\hline & & & & CHD1Z & Oporornis tolmiei & 3.E-48 & & \\
\hline 13 & Geospiza fuliginosa-3 & M & M & CHD1Z & Melanospiza richardsoni & 5.E-116 & & \\
\hline 14 & Camarhynchus psittacula-1 & $\mathrm{F}$ & $\mathrm{F}$ & CHD1W & Emberiza schoeniclus & 2.E-100 & 4 & 3 \\
\hline & & & & CHD1Z & Sporophila melanogaster & 7.E-30 & & \\
\hline 15 & Camarhynchus psittacula-2 & $\mathrm{F}$ & $\mathrm{F}$ & & & & & \\
\hline 16 & Camarhynchus psittacula-3 & M & M & CHD1Z & Tiaris olivacea & 2.E-174 & & \\
\hline 17 & Camarhynchus psittacula-4 & M & M & & & & & \\
\hline 18 & Camarhynchus parvulus-1 & M & M & CHD1Z & Sporophila hypoxantha & 3.E-132 & 0 & 1 \\
\hline 19 & Platyspiza crassirostris-1 & $\mathrm{F}$ & $\mathrm{F}$ & & & & 4 & 1 \\
\hline 20 & Platyspiza crassirostris-2 & $\mathrm{F}$ & $\mathrm{F}$ & CHD1W & Cardinalis cardinalis & 8.E-69 & & \\
\hline & & & & CHD1Z & Oporornis philadelphia & 1.E-52 & & \\
\hline 21 & Platyspiza crassirostris-3 & M & M & CHD1Z & Tiaris olivacea & 1.E-175 & & \\
\hline 22 & Negative control/Total & - & - & & & & 26 & 13 \\
\hline
\end{tabular}

PCR results using two primer sets. Sequencing results are shown for one female and one male per species, as top BLASTn results. The last column represents total number of embryos analysed by PCR. F-female; $\mathrm{M}-$ male.

analysis on $2 \%$ agarose gel of the PCR products of 24 samples with assigned but uncertain sex. Table 3 lists sample species shown in Fig 2, assigned sex using morphology, and PCR results. Of the 24 shown individuals, one had been sexed incorrectly in the field (highlighted in bold). Table 4 represents a summary of all results from blood samples. Importantly, the PCR approach revealed a sexing error of $12.6 \%$ : from the 278 birds with marginal sex, 35 had been assigned the wrong sex in the field. The distribution of the sexing error was highly dependent on species and sample size. C. parvulus showed the highest error rate (50\%) but very small sample size $(\mathrm{N}=2)$; G. fuliginosa had a large sample size $(\mathrm{N}=226)$ and an error rate of $8.4 \%$; while G. fortis had both high error rate $(30.6 \%)$ and reasonable sample size $(\mathrm{N}=49)$ (Table 4).

\section{Discussion}

In this study we applied an optimized PCR technique and successfully resolved the sex of nine species of Darwin's finches from both adult and embryonic samples. Accurate sex- 


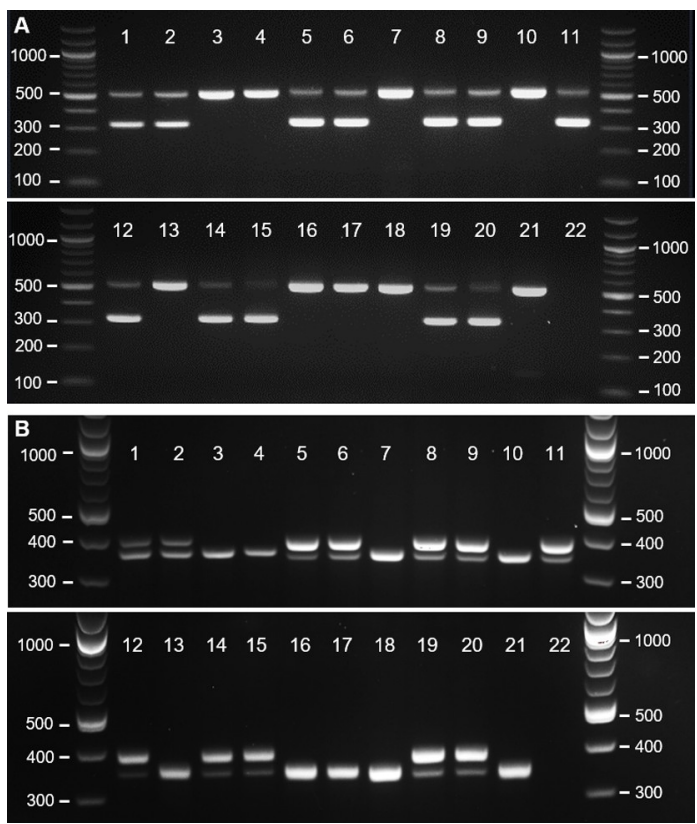

Fig 1. Gel electrophoresis of PCR products amplified using DNA extracted from embryonic tissues. (A) Results using the $\mathrm{mCHD} 1 \mathrm{~F} / \mathrm{mCHD} 1 \mathrm{R}$ primer pair. (B) Results using the mP2/P8 primer pair. Lane numbers correspond to the samples listed in Table 2.

https://doi.org/10.1371/journal.pone.0237687.g001

determination is necessary for a range of biological applications. For example, comparative transcriptomics, such as RNA-seq, is a vital tool in developmental biology. Sex-specific variation in gene expression can introduce bias when individual embryo specimens are compared. In multi-species comparisons, such as those on Darwin's finches, sex-related differences might be misinterpreted as inter-specific variation. Accounting for specimen sex is therefore essential for the accurate interpretation of expression data. In mice, sexually dimorphic gene expression in embryos starts as soon as the embryonic genome is activated at the two cell stage [41]. In chickens, such dimorphic expression is documented from at least as early as the blastoderm stage [42]. However, unlike the mouse model, where the expression profiles of many X-and $\mathrm{Y}$-linked genes are known [41], fewer W-specific genes are characterised in birds and their expression levels are tissue-specific and not known for many tissue types and stages [42]. Therefore, it can be challenging to determine sex in birds from RNA-seq data alone. PCR sexing from DNA might prove easier, faster and more reliable [43] especially in non-model organisms. Comparative studies based on fixed tissues are widely used in developmental biology, such as in situ hybridization and immunohistochemical stainings. While the DNA

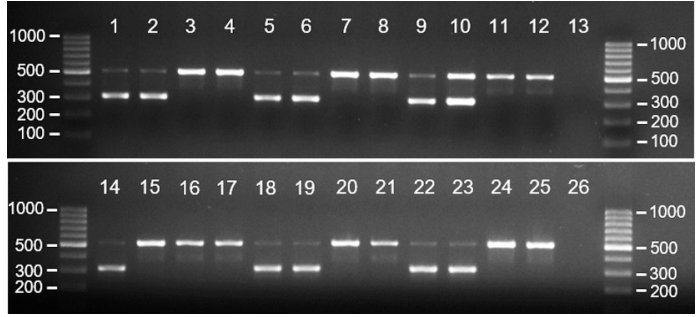

Fig 2. Gel electrophoresis of PCR products amplified using $\mathrm{mCHD1F} / \mathrm{mCHD} 1 \mathrm{R}$ primer pair and DNA extracted from blood. Lane numbers correspond to the samples listed in Table 3.

https://doi.org/10.1371/journal.pone.0237687.g002 
Table 3. Samples showed in Fig 2: Comparison between morphological and molecular sex identification using the mCHD1F/mCHD1R primer pair.

\begin{tabular}{|c|c|c|c|}
\hline Lane in Fig 2 & Species & Sex based on morphology & $\begin{array}{c}\text { Sex } \\
\text { based on PCR }\end{array}$ \\
\hline 1 & Geospiza fortis-1 & $\mathrm{F}$ & $\mathrm{F}$ \\
\hline 2 & Geospiza fortis-2 & $\mathrm{F}$ & $\mathrm{F}$ \\
\hline 3 & Geospiza fortis-3 & M & M \\
\hline 4 & Geospiza fortis-4 & M & M \\
\hline 5 & Geospiza fuliginosa-1 & $\mathrm{F}$ & $\mathrm{F}$ \\
\hline 6 & Geospiza fuliginosa-2 & $\mathrm{F}$ & $\mathrm{F}$ \\
\hline 7 & Geospiza fuliginosa-3 & M & M \\
\hline 8 & Geospiza fuliginosa-4 & M & M \\
\hline 9 & Geospiza scandens-1 & $\mathrm{F}$ & $\mathrm{F}$ \\
\hline 10 & Geospiza scandens-2 & $\mathrm{F}$ & $\mathrm{F}$ \\
\hline 11 & Geospiza scandens-3 & M & M \\
\hline 12 & Geospiza scandens-4 & M & M \\
\hline 13 & Negative control & - & - \\
\hline 14 & Camarhynchus pallidus-1 & $\mathrm{F}$ & $\mathrm{F}$ \\
\hline 15 & Camarhynchus pallidus -2 & $\mathbf{F}$ & $\mathbf{M}$ \\
\hline 16 & Camarhynchus pallidus-3 & M & M \\
\hline 17 & Camarhynchus pallidus -4 & M & M \\
\hline 18 & Camarhynchus parvulus -1 & $\mathrm{~F}$ & $\mathrm{~F}$ \\
\hline 19 & Camarhynchus parvulus-2 & $\mathrm{F}$ & $\mathrm{F}$ \\
\hline 20 & Camarhynchus parvulus-3 & M & M \\
\hline 21 & Camarhynchus parvulus-4 & M & M \\
\hline 22 & Certhidea fusca-1 & $\mathrm{F}$ & $\mathrm{F}$ \\
\hline 23 & Certhidea fusca-2 & $\mathrm{F}$ & $\mathrm{F}$ \\
\hline 24 & Certhidea fusca-3 & M & M \\
\hline 25 & Certhidea fusca-4 & M & M \\
\hline 26 & Negative control & - & - \\
\hline
\end{tabular}

F-female; $\mathrm{M}$-male.

https://doi.org/10.1371/journal.pone.0237687.t003

Table 4. Adult and juvenile Darwin's finches captured and sexed by morphology or later resolved by PCR.

\begin{tabular}{|c|c|c|c|c|c|c|c|c|c|c|c|c|c|c|c|}
\hline \multirow[t]{3}{*}{ Species } & \multirow[t]{3}{*}{ Total captured } & \multicolumn{7}{|c|}{ Sexing by morphology } & \multicolumn{7}{|c|}{ Sexing by PCR } \\
\hline & & \multicolumn{3}{|c|}{ Clear trait } & \multicolumn{3}{|c|}{ Marginal trait } & \multirow{2}{*}{$\begin{array}{c}\text { No trait } \\
\text { Total }\end{array}$} & \multicolumn{3}{|c|}{ All applications } & \multicolumn{3}{|c|}{ Misassigned sex } & \multirow{2}{*}{$\begin{array}{c}\text { Sexing error } \\
\% \\
\end{array}$} \\
\hline & & Total & $\mathbf{F}$ & $\mathbf{M}$ & Total & $\mathbf{F}$ & $\mathbf{M}$ & & Total & $\mathbf{F}$ & $\mathbf{M}$ & Total & $\mathbf{F}$ & M & \\
\hline Geospiza fuliginosa & 422 & 175 & 44 & 131 & 226 & 179 & 47 & 21 & 271 & 191 & 80 & 19 & 4 & 15 & 8.4 \\
\hline Geospiza fortis & 102 & 51 & 17 & 34 & 49 & 40 & 9 & 2 & 57 & 27 & 30 & 15 & 0 & 15 & 30.6 \\
\hline Certhidea fusca* & 7 & 6 & 2 & 4 & 0 & 0 & 0 & 1 & 6 & 3 & 3 & 0 & 0 & 0 & - \\
\hline Camarhynchus pallidus* & 4 & 1 & 0 & 1 & 0 & 0 & 0 & 3 & 4 & 1 & 3 & 0 & 0 & 0 & - \\
\hline Camarhynchus parvulus & 21 & 7 & 1 & 6 & 2 & 1 & 1 & 12 & 16 & 6 & 10 & 1 & 0 & 1 & 50 \\
\hline Geospiza scandens & 11 & 10 & 5 & 5 & 1 & 0 & 1 & 0 & 9 & 4 & 5 & 0 & 0 & 0 & 0 \\
\hline Total & 567 & 250 & 69 & 181 & 278 & 220 & 58 & 39 & 363 & 232 & 131 & 35 & 4 & 31 & 12.6 \\
\hline
\end{tabular}

Birds with marginal sex-specific morphology or undetermined sex were analysed by PCR. The sexing error represents the percentage of birds that were mis-assigned based on marginal sex-specific morphology. Numbers for mis-assigned sex reflect the PCR-determined sex, e.g., a count for male indicates a bird incorrectly sexed as a female in the field. PCR across all applications refers to birds with marginal or no sex-specific traits and birds with clear sex morphology sexed as proof of principle controls.

*Monomorphic species.

https://doi.org/10.1371/journal.pone.0237687.t004 
extracted from fixed tissues is often low in quantity and integrity, and therefore unsuitable for most applications, PCR amplification of relatively short DNA fragments remains viable [44]. Sexing by gonadal differentiation is possible in chicken embryos after a certain embryonic stage [3]. However, it requires dissection and is a laborious procedure to carry out for large numbers of individuals, particularly for embryos of smaller avian species. By comparison, molecular sexing is a much cheaper and faster alternative.

Ideally, DNA extraction and PCR reactions for sex genotyping, should be rapid and simple. Protocols to extract DNA from embryonic tissue that do not involve long protein digestion and cleaning steps are preferred and work equally well as lengthy overnight procedures [31]. Here, we apply the so-called alkaline method used previously on chicken embryos [31], with minor modifications. Alkaline lysis relies on solubilisation of proteins while DNA remains stable [45] and is a fast and simple strategy to obtain DNA from small amounts of tissues-it takes only 30 minutes. For fledged birds, we used the rapid and effective standard procedures of blood collection by brachial venepuncture [38] followed by DNA extraction. Where less invasive methods are required, e.g. for younger birds such as nestlings, DNA extracted from buccal swabs can be used for sexing [46].

Different primer sets based on the CHD1 gene have been used to sex birds [26, 28-30]. We chose two that have been successful in many passerines [27] and introduced minor modifications to their sequences. Our results confirm that both primer sets work clearly and easily to identify the sex of Darwin's finches (Figs 1 and 2).

There are two advantages to the molecular sexing of post-embryonic Darwin's finches. Firstly, juveniles, such as nestlings, fledglings, and young adults-usually in their first year of life, look alike. Secondly, in monomorphic species of Darwin's finches the colour of plumage and beak are the same in both sexes. Non-breeding birds lack traits such as protruding cloaca in males and brood patch in females, or they can be unclear. In these cases, molecular sexing can be used for either sex identification, or confirmation.

Strictly speaking, all Darwin's finches are sexually dimorphic in terms of size. Across the clade, male body and bill sizes are on average slightly larger than those of females [17, 47]. Interestingly, female warbler finches (Certhidea olivacea and C. fusca) have longer beaks than the males, which is a peculiar case of reversed sexual dimorphism where the directions of beak and body size dimorphisms do not match [47]. However, even though they are significant at the population level, differences in size cannot be used for accurate sexing because of the large marginal area where male and female individual sizes can overlap.

Molecular sexing might not be needed in long-term studies where individual birds are being followed through their lives and there is enough morphological and behavioural data [8]. This is especially true for dimorphic species, but even monomorphic species could be sexed fairly confidently based on mating behaviour, e.g. males building nests and singing, females assessing the nests and male fitness [8]. However, many studies, including this one, involve single capture and release in which case behavioural data and temporary traits may not be available. Attempts at molecular sexing of woodpecker and mangrove finches have been unsatisfactory, causing difficulties with the mangrove finch recovery plans [19, 20, 36]. The approach described here has the potential to save time and resources in future conservation projects. The only report on PCR sexing of Darwin's finches we are aware of uses primers described by Griffiths et al. [26] and includes 68 juvenile tree finches [48]. We successfully sexed 363 post-embryonic birds from six species of Darwin's finches, both dimorphic and monomorphic, and provide detailed optimised protocols.

As demonstrated by our study, visual sexing of Darwin's finches can be a source of uncertainty and can introduce significant error. This happens especially often with juveniles that have not yet developed sufficiently clear sexual dimorphism, and with birds that are studied 
outside of the mating season. It is of note that only $44 \%$ of all caught birds were sexed with confidence in the field based on morphological traits. In our hands, PCR sexing of the $42 \%$ "marginal" individuals revealed $13 \%$ rate of wrong sex assignment in the field across all species (Table 4). The error rate varied considerably between species, but so did the sample size. It is clear however that for G. fortis, where the sample size is adequate, the error rate of $31 \%$ is considerable. Males were misidentified much more frequently than females, which could be expected, as immature males resemble females. In addition, $7 \%$ of all caught birds were impossible to sex at all by morphology. Lastly, the experience of the handlers in the field could affect error rate. Less experience might result in greater error, but experienced handlers are not always available. In our experience, some error will persist even after years of handling. Our results show that post-embryonic PCR sexing is useful to both confirm uncertain sexing observations, and to identify sex. It enables cheap and rapid sexing whenever sex cannot be inferred from existing data (e.g., sequenced genomes) thus improving field studies on Darwin's finches.

In conclusion, we describe sexing of multiple individuals and species of Darwin's finches based on optimised existing protocols, easily and reliably and throughout ontogeny.

\section{Supporting information}

S1 Raw images.

(TIFF)

\section{Acknowledgments}

We want to thank Julia George and David Clayton at Queen Mary University of London who provided us with fertilized zebra finch eggs. We thank: Charles Darwin Research Station, Galápagos, for assistance with permit applications, administrative and logistical support; the Galápagos Science Center for support during laboratory work; and Galápagos Institute of Arts and Sciences (GAIAS)-Universidad San Francisco de Quito for logistical support.

\section{Author Contributions}

Conceptualization: Mariya P. Dobreva.

Formal analysis: Mariya P. Dobreva, Joshua G. Lynton-Jenkins.

Investigation: Mariya P. Dobreva, Joshua G. Lynton-Jenkins.

Methodology: Mariya P. Dobreva.

Project administration: Mariya P. Dobreva.

Resources: Mariya P. Dobreva, Joshua G. Lynton-Jenkins, Jaime A. Chaves, Masayoshi Tokita, Camille Bonneaud, Arkhat Abzhanov.

Supervision: Jaime A. Chaves, Camille Bonneaud, Arkhat Abzhanov.

Validation: Joshua G. Lynton-Jenkins.

Visualization: Mariya P. Dobreva.

Writing - original draft: Mariya P. Dobreva.

Writing - review \& editing: Mariya P. Dobreva, Joshua G. Lynton-Jenkins, Jaime A. Chaves, Masayoshi Tokita, Camille Bonneaud, Arkhat Abzhanov. 


\section{References}

1. Savalli UM. The Evolution of Bird Coloration and Plumage Elaboration. Current Ornithology. Boston, MA: Springer US; 1995. pp. 141-190. https://doi.org/10.1007/978-1-4615-1835-8_5

2. Coyne JA, Kay EH, Pruett-Jones S. The genetic basis of sexual dimorphism in birds. Evolution. 2008; 62: 214-9. https://doi.org/10.1111/j.1558-5646.2007.00254.x PMID: 18005159

3. Clinton M, Haines L, Belloir B, McBride D. Sexing chick embryos: a rapid and simple protocol. Br Poult Sci. 2001; 42: 134-8. https://doi.org/10.1080/713655025 PMID: 11337963

4. Morinha F, Cabral JA, Bastos E. Molecular sexing of birds: A comparative review of polymerase chain reaction (PCR)-based methods. Theriogenology. 2012; 78: 703-714. https://doi.org/10.1016/j. theriogenology.2012.04.015 PMID: 22704393

5. JONES RE. THE INCUBATION PATCH OF BIRDS. Biol Rev. 1971; 46: 315-339. https://doi.org/10. 1111/j.1469-185X.1971.tb01048.x

6. Wolfson A. The Cloacal Protuberance: A Means for Determining Breeding Condition in Live Male Passerines. Bird-Banding. 1952; 23: 159. https://doi.org/10.2307/4510381

7. Abzhanov A. Darwins Galápagos finches in modern biology. Philos Trans R Soc B Biol Sci. 2010; 365: 1001-1007. https://doi.org/10.1098/rstb.2009.0321 PMID: 20194163

8. Grant PR, Grant BR. 40 Years of Evolution. Princeton University Press; 2014. https://doi.org/10.2307/j. ctt5hhncc

9. Fessl B, Dvorak M, Hernan Vargas F, Glyn Young H. Recent conservation efforts and identification of the Critically Endangered Mangrove Finch Camarhynchus heliobates in Galápagos. Cotinga. 2011; 33: 27-33.

10. Cimadom A, Ulloa A, Meidl P, Zöttl M, Zöttl E, Fessl B, et al. Invasive Parasites, Habitat Change and Heavy Rainfall Reduce Breeding Success in Darwin's Finches. Moskát C, editor. PLoS One. 2014; 9: e107518. https://doi.org/10.1371/journal.pone.0107518 PMID: 25248092

11. Abzhanov A, Protas $M$, Grant BR, Grant PR, Tabin CJ. Bmp4 and morphological variation of beaks in Darwin's finches. Science. 2004; 305: 1462-5. https://doi.org/10.1126/science.1098095 PMID: 15353802

12. Abzhanov A, Kuo WP, Hartmann $C$, Grant BR, Grant PR, Tabin CJ. The calmodulin pathway and evolution of elongated beak morphology in Darwin's finches. Nature. 2006; 442: 563-7. https://doi.org/10. 1038/nature04843 PMID: 16885984

13. Mallarino R, Grant PR, Grant BR, Herrel A, Kuo WP, Abzhanov A. Two developmental modules establish 3D beak-shape variation in Darwin's finches. Proc Natl Acad Sci U S A. 2011; 108: 4057-62. https://doi.org/10.1073/pnas.1011480108 PMID: 21368127

14. Mallarino R, Campas O, Fritz JA, Burns KJ, Weeks OG, Brenner MP, et al. Closely related bird species demonstrate flexibility between beak morphology and underlying developmental programs. Proc Natl Acad Sci. 2012; 109: 16222-16227. https://doi.org/10.1073/pnas.1206205109 PMID: 22988109

15. Campàs $O$, Mallarino $R$, Herrel $A$, Abzhanov $A$, Brenner MP. Scaling and shear transformations capture beak shape variation in Darwin's finches. Proc Natl Acad Sci. 2010; 107: 3356-3360. https://doi.org/10. 1073/pnas.0911575107 PMID: 20160106

16. Lack D. Darwin's Finches. Cambridge: Cambridge University Press; 1947.

17. Grant BR, Grant PR. Mate choice in Darwin ‘s Finches. Biol J Linn Soc. 1987; 247-270.

18. Kleindorfer $S$. Nesting success in Darwin's small tree finch, Camarhynchus parvulus: evidence of female preference for older males and more concealed nests. Anim Behav. 2007; 74: 795-804. https:// doi.org/10.1016/j.anbehav.2007.01.020

19. Good H, Corry E, FessI B, Deem S. Husbandry Guidelines for the Woodpecker Finch (Camarhynchus pallidus) at Charles Darwin Foundation. Darwin Initiat. 2009. Available: https://www.darwininitiative.org. uk/documents/15005/21296/15-005 Woodpecker finch guidelines September 2009.pdf

20. Fessl B, Vargas H, Carrion V, Young R, Deem S, Rodriguez-Matamoros J, et al. Galápagos mangrove finch camarhynchus heliobates recovery plan 2010-2015. Darwin Initiat. 2010; 1-109. https://doi.org/ 10.13140/RG.2.1.1038.1680

21. Marshall Graves JA, Shetty S. Sex from W to Z: Evolution of vertebrate sex chromosomes and sex determining genes. J Exp Zool. 2001; 290: 449-462. https://doi.org/10.1002/jez.1088 PMID: 11555852

22. Griffiths R, Tlwarl B. Sex of the last wild Spix's macaw. Nature. 1995; 375: 454. https://doi.org/10.1038/ 375454a0 PMID: 7777052

23. Clinton M. A rapid protocol for sexing chick embryos (Gallus g. domesticus). Anim Genet. 1994; 25: 361-2. https://doi.org/10.1111/j.1365-2052.1994.tb00374.x PMID: 7818175 
24. Ellegren $\mathrm{H}$. First gene on the avian $\mathrm{W}$ chromosome (CHD) provides a tag for universal sexing of non-ratite birds. Proceedings Biol Sci. 1996; 263: 1635-41. https://doi.org/10.1098/rspb.1996.0239 PMID: 9025311

25. Griffiths R, Daan S, Dijkstra C. Sex identification in birds using two CHD genes. Proceedings Biol Sci. 1996; 263: 1251-6. https://doi.org/10.1098/rspb.1996.0184 PMID: 8858876

26. Griffiths R, Double MC, Orr K, Dawson RJG. A DNA test to sex most birds. Mol Ecol. 1998; 7: 10711075. https://doi.org/10.1046/j.1365-294x.1998.00389.x PMID: 9711866

27. Çakmak E, Akın Pekşen Ç, Bilgin CC. Comparison of three different primer sets for sexing birds. J Vet Diagnostic Investig. 2017; 29: 59-63. https://doi.org/10.1177/1040638716675197 PMID: 28074715

28. Lee JCI, Tsai LC, Hwa PY, Chan CL, Huang A, Chin SC, et al. A novel strategy for avian species and gender identification using the CHD gene. Mol Cell Probes. 2010; 24: 27-31. https://doi.org/10.1016/j. mcp.2009.08.003 PMID: 19716876

29. Vucicevic M, Stevanov-Pavlovic M, Stevanovic J, Bosnjak J, Gajic B, Aleksic N, et al. Sex Determination in 58 Bird Species and Evaluation of CHD Gene as a Universal Molecular Marker in Bird Sexing. Zoo Biol. 2013; 32: 269-276. https://doi.org/10.1002/zoo.21010 PMID: 22553188

30. SULANDART SRI, ZEIN MSA. Application of Two Molecular Sexing Methods for Indonesian Bird Species: Implication for Captive Breeding Programs in Indonesia. HAYATI J Biosci. 2012; 19: 183-190. https://doi.org/10.4308/hjb.19.4.183

31. Haunshi S, Pattanayak A, Bandyopadhaya S, Saxena SC, Bujarbaruah KM. A simple and quick DNA extraction procedure for rapid diagnosis of sex of chicken and chicken embryos. J Poult Sci. 2008; 45 : 75-81. https://doi.org/10.2141/jpsa.45.75

32. Turkyilmaz MK, Karagenc L, Fidan E. Sexing of newly-hatched chicks using DNA isolated from chorioallantoic membrane samples by polymerase chain reaction in Denizli chicken. Br Poult Sci. 2010; 51: 525-9. https://doi.org/10.1080/00071668.2010.502521 PMID: 20924847

33. Arnold KE, Orr KJ, Griffiths R. Primary sex ratios in birds: problems with molecular sex identification of undeveloped eggs. Mol Ecol. 2003; 12: 3451-8. https://doi.org/10.1046/j.1365-294x.2003.02007.x PMID: 14629359

34. Rutstein AN, Slater PJB, Graves JA. Diet quality and resource allocation in the zebra finch. Proceedings Biol Sci. 2004; 271 Suppl: S286-9. https://doi.org/10.1098/rsbl.2003.0154 PMID: 15503996

35. Gilbert L, Bulmer E, Arnold KE, Graves JA. Yolk androgens and embryo sex: maternal effects or confounding factors? Horm Behav. 2007; 51: 231-8. https://doi.org/10.1016/j.yhbeh.2006.10.005 PMID: 17187788

36. Tebbich S, Teschke I. Coping with uncertainty: Woodpecker finches (Cactospiza pallida) from an unpredictable habitat are more flexible than birds from a stable habitat. PLoS One. 2014; 9. https://doi.org/10. 1371/journal.pone.0091718 PMID: 24638107

37. Abzhanov A. Collection of embryos from Darwin's finches (Thraupidae, Passeriformes). Cold Spring Harb Protoc. 2009; 4. https://doi.org/10.1101/pdb.prot5174 PMID: 20147109

38. Owen JC. Collecting, processing, and storing avian blood: a review. J F Ornithol. 2011; 82: 339-354 https://doi.org/10.1111/j.1557-9263.2011.00338.x

39. Price TD. Sexual Selection on Body Size, Territory and Plumage Variables in a Population of Darwin's Finches. Evolution (N Y). 1984; 38: 327. https://doi.org/10.2307/2408491

40. Murray JR, Varian-Ramos CW, Welch ZS, Saha MS. Embryological staging of the Zebra Finch, Taeniopygia guttata. J Morphol. 2013; 274: 1090-110. https://doi.org/10.1002/jmor.20165 PMID: 23813920

41. Lowe R, Gemma C, Rakyan VK, Holland ML. Sexually dimorphic gene expression emerges with embryonic genome activation and is dynamic throughout development. BMC Genomics. 2015; 16: 295. https://doi.org/10.1186/s12864-015-1506-4 PMID: 25888192

42. Ayers KL, Davidson NM, Demiyah D, Roeszler KN, Grützner F, Sinclair AH, et al. RNA sequencing reveals sexually dimorphic gene expression before gonadal differentiation in chicken and allows comprehensive annotation of the W-chromosome. Genome Biol. 2013;14. https://doi.org/10.1186/gb-201314-3-r26 PMID: 23531366

43. Zhuo Z, Lamont SJ, Abasht B. RNA-Seq Analyses Identify Frequent Allele Specific Expression and No Evidence of Genomic Imprinting in Specific Embryonic Tissues of Chicken. Sci Rep. 2017; 7: 1-10. https://doi.org/10.1038/s41598-017-12179-9 PMID: 28931927

44. Dietrich D, Uhl B, Sailer V, Holmes EE, Jung M, Meller S, et al. Improved PCR Performance Using Template DNA from Formalin-Fixed and Paraffin-Embedded Tissues by Overcoming PCR Inhibition. PLoS One. 2013; 8: 1-10. https://doi.org/10.1371/journal.pone.0077771 PMID: 24155973

45. Rudbeck L, Dissing J. Rapid, simple alkaline extraction of human genomic DNA from whole blood, buccal epithelial cells, semen and forensic stains for PCR. Biotechniques. 1998; 25: 588-90, 592. https:// doi.org/10.2144/98254bm09 PMID: 9793639 
46. Adam I, Scharff $C$, Honarmand $M$. Who is who? Non-invasive methods to individually sex and mark altricial chicks. J Vis Exp. 2014. https://doi.org/10.3791/51429 PMID: 24893585

47. Grant PR, Grant BR. Reversed sexual dimorphism in the beak of a finch. Ibis (Lond 1859). 2003; 145 : 341-343. https://doi.org/10.1046/j.1474-919X.2003.00157.x

48. Peters KJ, Myers SA, Dudaniec RY, O'Connor JA, Kleindorfer S. Females drive asymmetrical introgression from rare to common species in Darwin's tree finches. J Evol Biol. 2017; 30: 1940-1952. https:// doi.org/10.1111/jeb.13167 PMID: 28833876 